\title{
ERRATUM
}

\section{The 'wildtype' conformation of p53: epitope mapping using hybrid proteins}

Peter L Wang, Fiona Sait and Greg Winter

Correction to: Oncogene (2001) 20, 2318-2324.

Due to a typesetting error, Figure 3 of the above paper was reproduced incorrectly. The correct version of Figure 3 is reproduced below.

In addition, the author has identified an error in the reference to (Wang, 2001). The reference to this paper should read:

Wang PL. (2000). Disease Markers, 16, 3-13.

a.

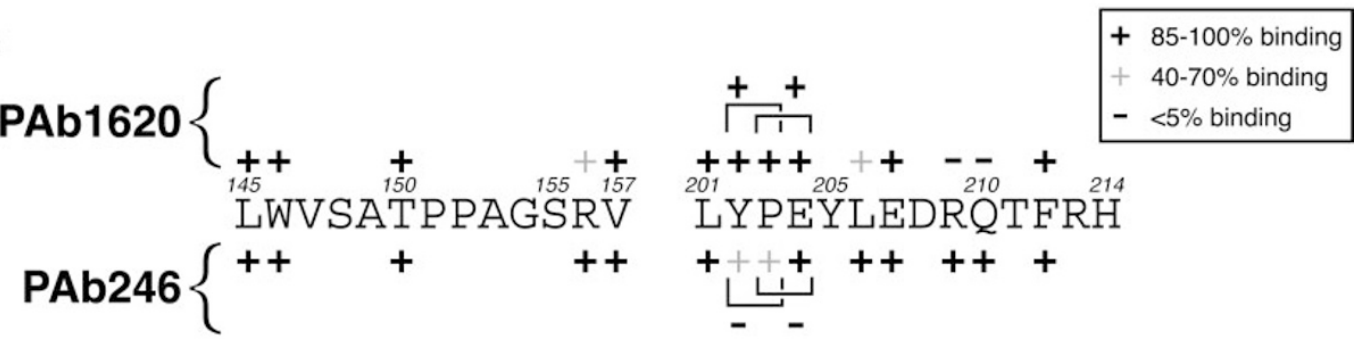

b.

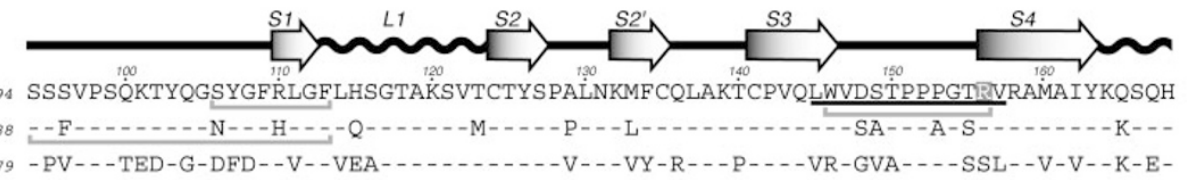

human 94 SSSVPSQ்KYYGSYGFRLGFLHSGTAKSVTCTYSPALNKMFCQLAKTCPVQLWVDSTPPPGTRVRAMAIYKQSQH

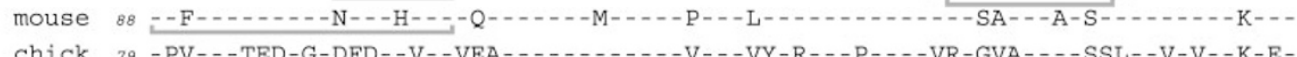

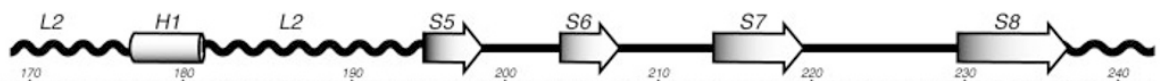

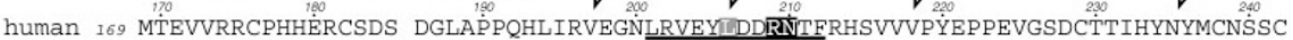

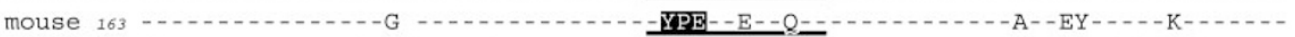

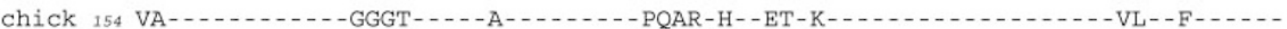

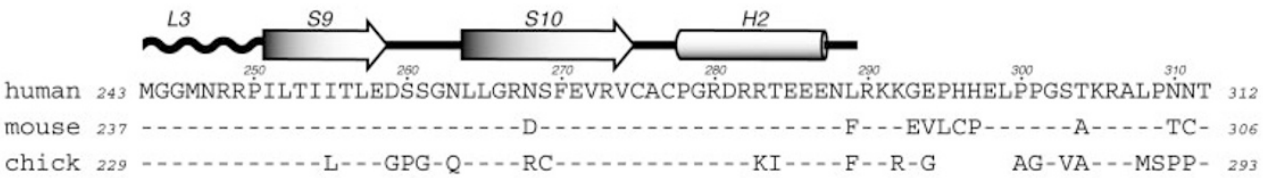

